A Work Project presented as part of the requirements for the Award of a Master Degree in Management from the NOVA - School of Business and Economics.

\title{
CREDIT PORTABILITY AND SPREADS: EVIDENCE IN THE BRAZILIAN MARKET
}

\author{
GABRIELA AVANCINI RODRIGUES \\ \#27612
}

A Project carried out on the Master in Management Program, under the supervision of:

Professor Miguel A. Ferreira, PhD

$07 / 2017$ 


\section{CREDIT PORTABILITY AND SPREADS: EVIDENCE IN THE BRAZILIAN MARKET}

This study examines possible impacts in the Brazilian credit market as a result of the portability resolution. This new law increases the ease of borrowers to change from one financial institution to another whenever borrowers have access better credit conditions. It is expected an increase in the market competition and consequently a decrease of price formation power for these institutions. Using difference-in-differences methodology for 231 Brazilian financial institutions, we find that credit spreads for types of credit susceptible to portability are lower than credit spreads for other types of credit that not benefited by the new law.

Key-Words: Credit. Portability. Spread. 


\section{Introduction}

The Brazilian banking market has a high market concentration. In the second half of 2016, the country's three largest banks held $50 \%$ of the total national assets (BCB 2017a). The high concentration of financial institutions in the Brazilian credit market has resulted in a high power of price formation for creditors. The Brazilian bank spread, which is one of the largest compared to the spread in other countries (Lavoratti 2010), is one of the results of this market power.

Because of this significant market power, larger financial institutions may price above the marginal cost, generating positive economic returns. For the credit market, the prices charged can be translated into fees and interest rates or even the bank spread. The difference between the rate charged on the loan and the rate paid for funding the resource represents the spread of the credit operation (Pereima and de Pauli 2008). It is worth noting that market concentration alone does not influence the spread. Factors such as basic interest rates, gross domestic product (GDP), inflation, and operating costs are other determinants of the Brazilian bank spread.

Central Bank of Brazil (Banco Central do Brasil - BCB) Resolution 4,292 encourages an increase in bank competition through credit portability. Portability aims to facilitate the transfer of credit among financial institutions, making these credit substitutes closer and reducing the market power to define prices for companies operating in the market. As a result, the market prices of dominant firms tend to be reduced.

Almeida (2015) note that the increase in competition from credit portability could be so large that, if credit portability did not present any cost to customers, institutions could enter into a price war to win customers. Considering this scenario, we aim to identify the effect of the credit portability resolution on competition in the financial sector and then the economic impact for borrowers. 
In 2014, this resolution came into force in Brazil, making the portability process, which has existed since 2006, more transparent and standardized and imposing deadlines for the financial institutions involved in the portability process. Figure 1 shows the behavior of the portabilityderived credit volume in relation to the total credit volume in the Brazilian market, in addition to the average number of transactions per month. The portability-derived share of the total credit volume and the number of transactions have grown after the change in the portability resolution. The decrease in the number of transactions transferred in 2014 may have been a consequence of the learning curve for the new portability process.

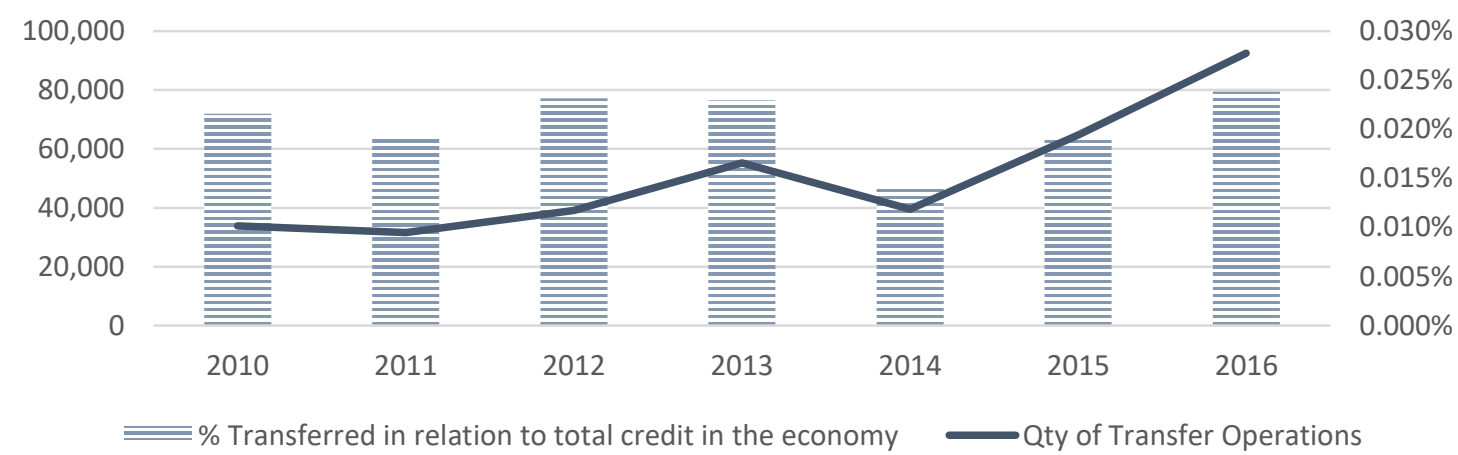

Figure 1. Data on portability in Brazil

Source: $B C B$ (prepared by the author)

In the second half of 2016, credit portability difficulties ranked sixth in the BCB ranking of reasons for complaints. This ranking presents 119 causes for disputes to the BCB. Complaints specific to payroll-deductible loans hold second place in the ranking for the same period. The reason is that payroll loans are responsible for most of the transfer transactions. In 2015, this type of credit represented $99 \%$ of the transfer transactions (FEBRABRAN 2015).

\section{Literature Review}

\subsection{Brazilian banking market}

The Brazilian banking sector has a high concentration. According to Figure 2, the three largest Brazilian banks own approximately $50 \%$ of total assets. This concentration started from the 
Real Plan ${ }^{1}$ and has remained since. Mergers and acquisitions in this sector helped banks with national capital increase their holdings in the market, reducing the share of banks with foreign capital (Pereima and de Pauli 2008). In this manner, national banks were able to increase their efficiency with economies of scale and scope, creating barriers for new entrants (Rocha and Oreiro 2009). The degree of competition in this sector is also affected by other aspects, such as regulations in the sector and the performance of public banks (Martins 2012).

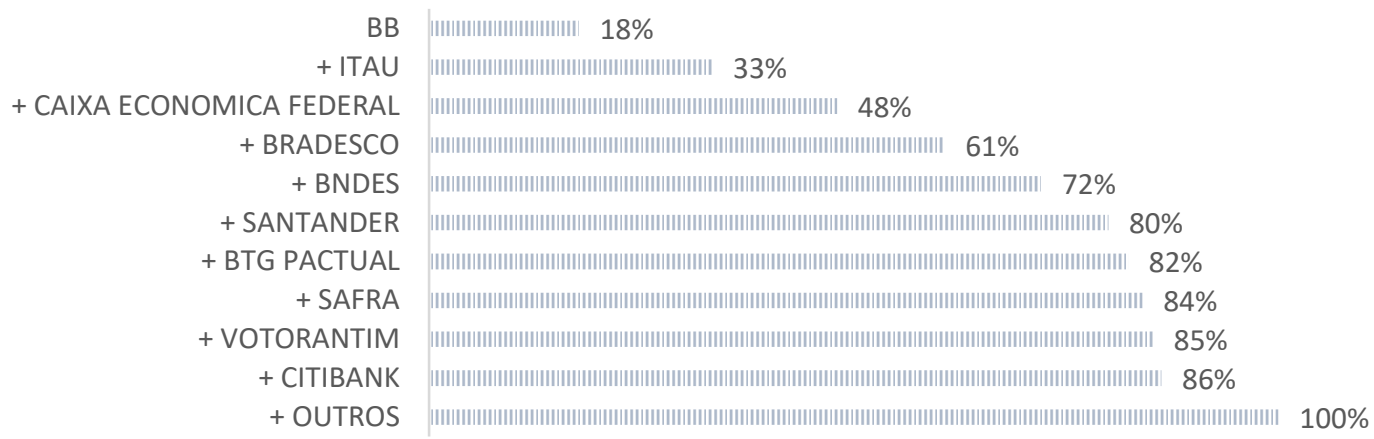

Figure 2 Accumulated market share of the 10 largest Brazilian banks by total assets (2nd half of 2016) Source: $B C B$ (prepared by the author)

By analyzing the credit market in Brazil, we note that although Pereima and Pauli (2008), Rocha and Oreiro (2009), and Martins (2012) emphasize that the banking market is concentrated, the Herfindahl-Hirschman Index $\left(\mathrm{HHI}^{2}\right)$, calculated based on the assets of financial institutions, indicates that this market is moderately concentrated (CADE 2016). This behavior can be explained by the fact that there are smaller financial institutions that are part of large conglomerates. Because, in this case, we are analyzing the institutions and not the conglomerates, the concentration becomes slightly more diluted than would be expected. Figure 3 presents the HHI calculated for the period from January 2012 until early 2017.

\footnotetext{
1 The Real Plan was a monetary reform in the Brazilian market that reduced inflation through the creation of the Brazilian real - a new Brazilian currency (BACHA 1997). With price stability, financial institutions needed to adapt to the new market by reducing the number of institutions present in this market (BCB 2017b)

2 The HHI was calculated as described in Besanko et al. (2009)
} 


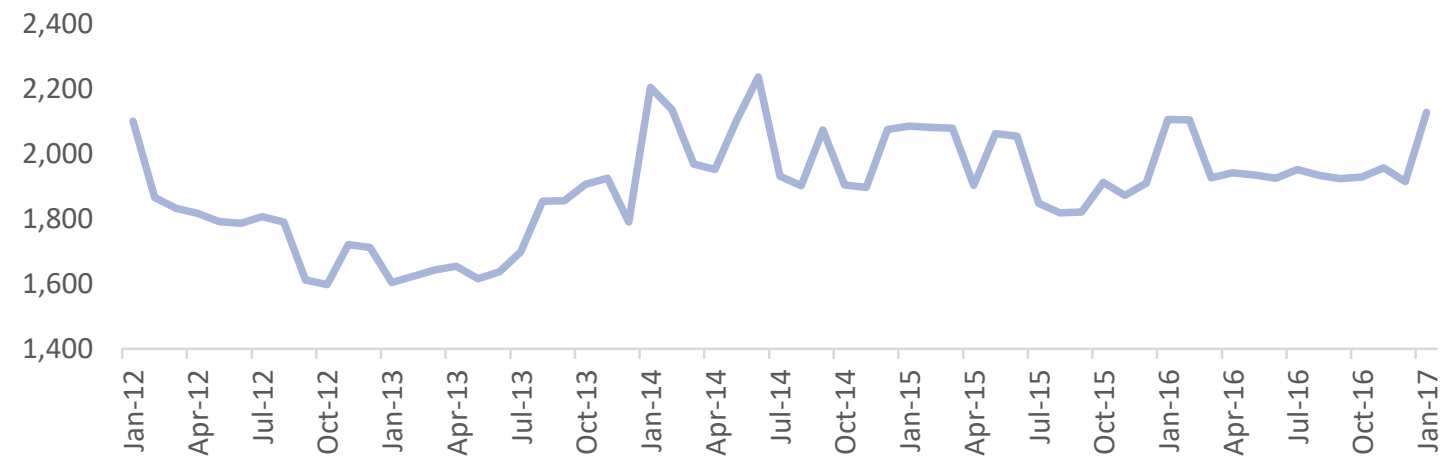

Figure 3. HHI calculated for the Brazilian credit market.

Source: $B C B$ (prepared by the author)

Oreiro et al. (2006) and Martins (2012) suggest that this concentration leads the banking market to oligopolistic behavior, such that the services provided by financial institutions are substitutes and almost homogeneous. However, substitution is not so simple. The client must have a relationship with the financial institution, for example, an open checking account, to be able to borrow certain loans. Therefore, there is an implicit cost of change.

It is believed that competitors are more profitable in more concentrated markets for two main reasons. First, the most efficient companies tend to grow and stay in the market. Second, high concentration also increases the market power of firms in price formation, which, for the banking sector, indicates that spreads will be higher (Martins 2012).

Geographical extent may also interfere with the degree of local banking concentration. The greater the capillarity of institutions in a given region is, the lower the concentration. Although there were 1,052 credit unions and 156 banks registered in February 2016 with the BCB, most financial institutions operate only in commercial centers. Thus, only large institutions have access to local markets, making them even more concentrated (Martins 2012).

Analyzing the Brazilian credit market, we observe that market regulations cooperate for the existence of supply rationing, which means that supply is more important than demand in defining the volume of credit available in the market (Laux 2013). Laux (2013) notes that the Brazilian 
market is conservative in offering credit, which indicates that an increase in supply would most likely be consumed by demand.

Regarding the profitability of credit operations, Martins (2012) has shown that the profitability of credit operations for natural persons is different from that obtained for credit to legal persons. In this manner, the cost of credit would be higher in retail markets than in corporate markets (Martins 2012).

\subsection{Bank Spread}

Brazilian banks have two main sources of revenue. The first and oldest is obtained through the bank spread derived from financial intermediation; that is, the spread is obtained through the transfer from economic agents that have resources available to economic agents that need financial resources. The second source comes from the fees charged for services rendered (Pereima and de Pauli 2008). In this study, we focus on the first source of revenue, that is, the spread.

Analyzing the credit market, one can observe that the difference between the rate charged on the loan and the rate paid to fund the asset represents the spread of the credit operation (Pereima and de Pauli 2008). That is, the spread represents the banks' compensation when intermediating the credit transaction (Bignotto and de Souza Rodrigues 2005).

Rocha and Oreiro (2009) present two models that help in understanding how the spread is established. The banking industry model considers that banks function in a manner similar to other sectors of the economy, such that profit maximization occurs when the marginal cost and marginal revenue are equal. This model concludes that the greater the market power of banks, the higher the spread. In addition, the model indicates that the greater the number of companies competing, the greater the competition, which reduces the spread. Therefore, market power, intermediation costs, reserve requirements, and the interbank interest rate affect the spread (Rocha and Oreiro 2009). 
However, as noted above, the fact that the Brazilian banking market has an oligopolistic behavior, added to the existence of substitution costs for the clients, contributes to the formation of barriers to entry.

The model of financial intermediation costs considers that banks are only intermediaries in the credit process. In addition, banks have uncertainties that are related to two items. The first is the possible lack of synchronization between borrowers and depositors. The second uncertainty is related to delinquency (Rocha and Oreiro 2009).

Based on this model, studies have proposed factors that influence the definition of the spread practiced by Brazilian banks, as shown in Table 1. Authors argue that the correlation between the country's basic interest rate and the spread of banking operations occurs because, given that there are securities indexed to the Selic rate ${ }^{3}$ that are part of the investment portfolios of banks, the opportunity cost of lending money tends to follow the rate.

However, this component alone does not interfere in the bank spread. Pereima and Pauli (2008), Dantas, Medeiros, and Capelleto (2012) and Oreiro et al. (2006) consider factors such as operation costs (including taxation under the credit operations), risks associated with this operation (the specific risk of the customer and the guarantee), the macroeconomic situation of the country (e.g., the level of Inflation), and the conditions of the operation, such as term and volume. In their study on the U.S. market, Collin-Dufresn, Goldstein, and Martin (2001) note that although the spread is related to credit risk, variations in the spread tend to be more related to local supply shocks than to credit risk factors.

Theory indicates that one of the main items that determines the spread is the degree of risk aversion of the bank that is granting the loan (Matthews and Thompson 2008). As a consequence

\footnotetext{
${ }^{3}$ Selic is the basic interest rate in Brazil, established periodically by the BCB through the Monetary Policy Committee.
} 
of this scenario, the Brazilian market has high interest rates, which leads to a low share of credit in the country's GDP but indicates a high profitability of the banking sector compared to other sectors of the Brazilian economy (Pereima and de Pauli 2008). High spread levels indicate inefficiency in the sector and increase the costs of borrowers.

Studies prepared by the $\mathrm{BCB}^{4}$ have identified that the spread in the Brazilian market has a significant relationship with the Selic rate, inflation, the economic activity level, the average reserve ratio, credit risk, intermediation costs, bank size, the service fee, liquidity, market share, and the share of foreign banks in the Brazilian market. These studies basically differ in relation to the period analyzed, the methodology, and the type of spread used (ex-ante or ex-post). In Table 1, the main articles on the definition of the bank spread in the Brazilian market are presented.

In general, the results show that banks with healthier credit portfolios, that is, those with less delinquency, charge lower rates in their credit transactions. Furthermore, the larger the bank is, the lower the rate, such that the benefits obtained from economies of scale are passed on to a certain degree to the banks' borrowers (Dantas, Medeiros, and Capelleto 2012).

Additionally, the hypothesis that there is an increase in the spread practiced in concentrated markets and that the ex-post spread is related to the historical behavior of the spread is reinforced (Dantas, Medeiros, and Capelleto 2012). Finally, GDP and the Selic rate are significant variables in most studies, indicating that the economic situation of the country influences the definition of the spread.

\footnotetext{
${ }^{4}$ Studies published by the BCB, such as Trabalhos para Discussão ("Works for Discussion"): Bignotto and de Souza Rodrigues (2005), Dantas, Medeiros, and Capelleto (2012) and Martins (2012).
} 
Table 1. Brazilian studies that analyze the determinant factors of bank spread in the Brazilian market.

\begin{tabular}{|c|c|c|}
\hline Study & Measure of spread & Relevant statistically explanatory variables with signal \\
\hline Koyama and Nakane (2001a) & Ex-ante & Selic rate $(+)$; Spread over treasury $(+)$; Indirect taxes (+); administrative cost $(+)$ \\
\hline Koyama and Nakane (2001b) & Ex-ante & $\begin{array}{l}\text { General Price Index (Índice Geral de Preços - IGP) (+); industrial product (-); spread } \\
\text { over treasury }(+) \text {; indirect taxes }(+) \text {; reserve requirement }(+) \text {. }\end{array}$ \\
\hline \multirow{2}{*}{$\begin{array}{l}\text { Afanasieff, Lhager and Nakane } \\
\text { (2001) }\end{array}$} & \multirow[t]{2}{*}{ Ex-ante } & $\begin{array}{l}\text { In the first stage: operational cost }(+) \text {; borrowing without cost of interest }(+) \text {; revenue } \\
\text { from services }(+) \text {. }\end{array}$ \\
\hline & & $\begin{array}{l}\text { In the second stage: GPI (+); growth of industrial product }(+) \text {; Selic rate }(+) \text {; Selic rate } \\
\text { volatilitv (-) }\end{array}$ \\
\hline \multirow{2}{*}{$\begin{array}{l}\text { Afanasieff, Lhager and Nakane } \\
\text { (2002) }\end{array}$} & \multirow{2}{*}{ Ex-ante } & $\begin{array}{l}\text { In the first stage: operational cost }(+) \text {; borrowing without cost of interest }(+) \text {; revenue } \\
\text { from services }(+) \text {; foreign banks }(-) .\end{array}$ \\
\hline & & $\begin{array}{l}\text { In the second stage: GPI }(-) \text {; growth of industrial product }(+) \text {; Selic rate }(+) \text {; spread over } \\
\text { treasury }(+) \text {; indirect taxes }(+) \text {. }\end{array}$ \\
\hline Bignotto and Rodrigues (2005) & Ex-ante & $\begin{array}{l}\text { Extended National Consumer Price Index (Índice de Preços ao Consumidor Amplo - } \\
\text { IPCA) (-); Selic rate (+); administrative cost (=); risk of interest rates }(+) \text {; risk of credit } \\
(+) \text {; mandatory (=); total assets (+). }\end{array}$ \\
\hline Oreiro et al. (2006) & Ex-ante & Industrial product (+); Selic rate (+); Selic rate volatility (+). \\
\hline Guimares (2002, apud LEAL, 2007) & Ex-post & Share of foreign banks $(+)$; cash and deposits $(+)$. \\
\hline Rocha and Oreiro (2009) & Ex-ante & Selic rate (+); Credit/GDP (+); Exchange risk (-); country risk (+); inflation (-). \\
\hline $\begin{array}{l}\text { Dantas, Medeiros and Capelletto } \\
\text { (2012) }\end{array}$ & Ex-post & $\begin{array}{l}\text { Risk of credit (+); Share of institution in the credit market (-); HHI (degree of market } \\
\text { concentration) (+); GDP (+). }\end{array}$ \\
\hline
\end{tabular}

Source: Dantas, Medeiros, and Capelleto (2012) - (Adapted)

\subsection{Credit portability}

Credit portability aims to enable better credit conditions negotiated by clients because the client may transfer the transaction to an institution that provides better conditions (BCB 2014).

In terms of process, what occurs in credit portability is the liquidation of the transaction in the earlier institution and the creation of a new transaction in another institution. The advantage for the debtor is that he/she will be free from costs and taxes with respect to this transfer. Legislation on credit portability began in 2006 and was revised in 2013-14. This revision sought to facilitate and standardize the portability process between banks to make the process more agile and transparent. Furthermore, these changes sought to increase competition between financial institutions. Increased competition would lead to reduced interest rates charged by institutions (Almeida 2015). 
Resolution 4,292, from December 20, 2013, came into force in May 2014; it requires financial institutions to use an electronic register authorized by the $\mathrm{BCB}$ to exchange information among themselves, comply with the terms to exchange this information, not pass costs to clients, and not oppose portability for credit to natural persons (BCB 2013). Table 2 shows the details of the change in the portability resolution.

Table 2. New rules for credit portability - Resolution 4,292/2013, in force since May 5, 2014

\section{New rules for credit portability}

A) It is mandatory to use the electronic system to exchange information between the original credit institution (holder of the transaction to be liquidated) and the proponent institution (offerer of the new credit to liquidate the original transaction);

b) it is prohibited to use alternative procedures to create portability, such as the use of payment bills;

c) the value and term of the new transaction should be limited to the value of the outstanding balance and the remaining term of the original transaction;

d) the original credit institution has up to 5 business days to demonstrate customer maintenance or to send the information to the proponent institution to finalize portability;

e) resource transfer between institutions should be conducted through the Available Electronic Transfer (Transferência Electrônica Disponível - TED)

f) one cannot pass on to the client the costs of resource transfer between the institutions involved;

g) once the request for portability is made, it is prohibited for the original credit institution to refuse to follow the flow of portability.

Source: BCB (2014) - Adapted

In their study, Almeida (2015) emphasize that if there are no portability costs and there are few clients in the market, institutions will charge lower rates. They will attract more clients. However, larger institutions will survive to this price war, turning into an oligopolistic market again. So, the rates will rise again, such that only large institutions will benefit from this regulation.

In a more realistic scenario, in which there are a large number of clients and financial institutions competing for loans, the results of the studies indicate that the profits of institutions are 
larger when they have similar rates than when one institution has a different rate. Then, changing rates would cause a price war, hurting the institutions themselves (Almeida 2015).

Almeida (2015) further add to this, inferring that if there were a cost in portability, the institutions would not enter into a detrimental price war that would reduce the national financial results; however, there would be competition for prices.

On the other hand, credit portability encourages the exchange of information between institutions because to transfer credit to another institution, the client must present data from the previous contract to the new financial institution. Sharing information increases the share of private credit in the economy. The reason is that the more information about the client the institution has, the more precise the definition of customer characteristics that are related to credit risk profiles (Djankov, McLiesh, and Shleifer 2007).

\section{Methodology}

\subsection{Definition of hypotheses}

This study evaluates whether there was a change in the banking sector after Resolution 4,292 for credit portability. The purpose of this resolution is to facilitate and standardize the credit portability process, which would thus encourage clients to migrate from an institution if they identified a more attractive institution. Because credit products are near-perfect substitutes, for borrowers, a more attractive bank means that the loan costs will be lower. The main factor in the cost of a loan is the spread practiced by the lending institution. In this sense, we expect that the bank spread will be reduced after Resolution No. 4,292. In this manner, we define the following:

Hypothesis: Resolution 4,292 led to a reduction of the spread practiced by financial institutions in the Brazilian market. 
However, if institutions reduce their spreads, a price war could be caused, as highlighted by Almeida (2015). In addition, since Resolution 4,292 encourages the exchange of information between such institutions, one result could be the creation of tacit collusion, leading the spread to be maintained at its previous levels or even higher.

\subsection{Definition of the method}

To evaluate the impact of Resolution 4,292, we use the quasi-natural experiment methodology with difference in differences regression. As indicated by Wooldridge (2006), natural experiments occur when exogenous events change the environment. In these cases, there will always be a group of individuals who are not affected by the exogenous effect; they are called the untreated group, whereas the group of individuals affected by the change are the treatment group.

In this case, our exogenous event is Resolution 4,292, which changed the environment of the banking market, mainly from the perspective of the spread for credit operations practiced in this market. Because this legislation was applied only to natural persons, the treatment group includes credit operations for natural persons. We withdraw from the treatment group only revolving credit operations because although the legislation applies, in practice, clients do not have incentives to carry this type of credit, given that it is a very short-term and extremely expensive loan. The interest rates are much higher than any other type of credit. In January 2017, for example, the average interest rate of this modality was $486.7 \%$ per year. In this manner, credit modalities for legal persons were considered in the untreated group, in addition to revolving credit for natural persons.

Applying this methodology, we have Equation 1 as an equation of interest. In this equation, the parameter $\beta_{3}$ measures the effect of treatment in the treatment group.

$$
y=\beta_{0}+\beta_{1} * D_{\text {port }}+\beta_{2} * D_{\text {treat }}+\beta_{3} * D_{\text {port }} * D_{\text {treat }}+\text { control variables }+\varepsilon
$$


where, $\mathrm{y}$ is the dependent variable; $D_{\text {treat }}$ is a dummy variable, which takes the value of 1 if the individual belongs to the treatment group and 0 otherwise; and $D_{\text {port }}$ is a dummy variable, which takes the value of 1 if it is the period after the exogenous event (change in the resolution on portability) and 0 otherwise.

Control variables have the objective of controlling changes in the environment that do not affect the two groups in the same manner and impact the variable of interest $(\boldsymbol{y})$.

For hypothesis of this study, our main dependent variable is the spread practiced by banks in credit operations. The control variables are the characteristics of banks operating in the market, macroeconomic information and characteristics of type of borrowers. Equation 2 represents the specified regression, detailing the variables used for fixed effects.

$$
\begin{gathered}
\operatorname{spread}_{\text {tbmep }}=\beta_{0}+\beta_{1} * D_{\text {port }}+\beta_{2} * D_{\text {trat }}+\beta_{3} * D_{\text {port }} * D_{\text {trat }}+\beta_{4} * \delta_{\mathrm{t}}+\beta_{5} * \delta_{\mathrm{b}}+\beta_{6} * \\
\delta_{\mathrm{m}}+\beta_{7} * \delta_{\mathrm{e}}+\beta_{8} * \delta_{\mathrm{p}}+\text { control var. }{ }_{\text {tb }}+\text { control var. }{ }_{\mathrm{t}}+\text { control var.tp }_{\text {tp }}+\varepsilon_{\text {tbmep }}
\end{gathered}
$$

where, spread tbmep $_{\text {is }}$ the spread for period $\boldsymbol{t}$ reported by financial institution $\boldsymbol{b}$ in credit modality $\boldsymbol{m}$ with type of charge $\boldsymbol{e}$ and for type of borrower $\boldsymbol{p} ; D_{t}$ is a dummy for each month of the period analyzed; $D_{b}$ is a dummy for each of the financial institutions analyzed; $D_{m}$ is a dummy for each type of loan; $D_{e}$ is a dummy for each type of charge; and $D_{p}$ is a dummy that indicates whether the borrower is a natural person or a legal person. Seven different regression specifications were defined. For the first, no control variables or fixed effects were introduced. For the second, control variables were introduced. From the third to the seventh specification, the fixed effects variables were introduced. We individually considered the five fixed effects variables to identify the individual impact generated by each variable. All regressions report robust standard errors ${ }^{5}$.

\footnotetext{
${ }^{5}$ Clusters by credit modality, financial institution, type of person or type of charge were also considered for robustness. In all these specifications the results remain statistically significant at 5\% level (except financial institution, which is significant at $10 \%$ level).
} 
In addition, to evaluate the robustness of the results found, the matching methodology was adopted, following Abadie and Imbens (2011). The matching used in this study considers a probit 1-1 model. The variables used for matching were the characteristics of financial institutions and the modality of each observation in the month prior to the implementation of Resolution 4,292.

Our sample used a 61-month period (January 2012 to January 2017), of which 28 months were before the implementation of Resolution 4,292 and 33 months were after implementation. In addition, we used data from 231 Brazilian financial institutions to create groups of analysis.

\subsection{Data}

Data on the Brazilian banking market were collected through two main sources of data: the BCB and the Institute of Applied Economic Research (Instituto de Pesquisa Econômica Aplicada - IPEA). These data were obtained for all financial institutions that reported to the BCB the interest rate practiced for at least one month from January 2012 to January 2017. In total, 231 financial institutions ${ }^{6}$ operating in the Brazilian credit market were considered in this sample, comprising public, private, publicly held, and privately held institutions. The data are organized in panels; thus, each observation is defined by the combination of: the modality of the loan, the type of charge, the type of borrower, and the creditor financial institution. Thus, a single observation is defined for each period of study.

The data sample contains monthly information on the rate practiced by each financial institution in the Brazilian market for the 20 credit modalities $^{7}$ defined by the BCB. For each

\footnotetext{
6 The following financial institution classifications are considered in this study: credit, financing and investment companies, leasing companies, savings and loans associations, real estate mortgage companies, commercial banks, multi-service banks, investment banks, cooperative commercial banks, multi-service cooperative banks, mortgage companies, development banks, foreign commercial banks-country branch, federal savings banks, and real estate credit companies-distributor and securities distribution company.

${ }^{7}$ Credit modalities: acquisition of other goods, acquisition of vehicles, credit card installment, revolving credit card, overdraft, Brazilian National Social Security Institute (Instituto Nacional do Seguro Social - INSS) payroll deduction, private personal payroll deduction, public personal payroll deduction, check discounting, real estate financing with regulated rates, real estate financing with market rates, uncollaborated personal loans, leasing of vehicles, advance
} 
modality, we have the type of charge ${ }^{8}$ and the type of person to whom the credit is intended (natural or legal), in addition to the interest rates practiced by these institutions (presented as a percentage per month (p.m.) and percentage per year (p.y.)).

The spread used is ex-ante, which, by definition, is the spread that institutions expect to obtain according to their expectations of the behavior of operations costs and risk factors (Dantas, Medeiros, and Capelleto 2012). Because we cannot access the information on funding costs for each type of credit, we opted for an approximation through the basic interest rates of the Brazilian economy (Selic). In addition, we control for several financial characteristics of each institution, which are directly related to the cost of funding, mitigating some of the adverse effects of this approach.

Thus, the bank spread considered for this study consists of the difference between the interest rate practiced by the institution and the Selic interest rate for the same period if the type of charge of the loan analyzed is pre-fixed. For the post-fixed interest rate tied to the reference rate (Taxa Referencial - TR), the spread is the interest rate applied plus TR minus the Selic rate for the same period. Finally, for the post-fixed interest rate tied to floating interest, the spread is the interest rate itself. For this study, we disregard the interest rate tied to foreign currency.

For the same period, information referring to the characteristics of the banks and characteristics of the Brazilian market was collected. This information helps control factors that may have influenced the market beyond the change in Resolution 4,292. With regard to Brazilian banks, it was possible to collect monthly accounting and registration information. In addition, we

credit card invoices, working capital with a term of up to 365 days, working capital with a term exceeding 365 days, guaranteed account, trade bill discounting, vendor, and advance on exchange contracts.

${ }^{8}$ Modalities of charge: pre-fixed, post-fixed tied to TR, post-fixed tied to floating interest, and post-fixed tied to foreign currency. 
collected macroeconomic information to control for other possible factors that could affect the consistency of the estimate.

To define the macroeconomic variables used, we considered the studies on the definition of spread in the Brazilian market, presented in Table 1. The variables selected were GDP, inflation, the Selic rate, default rate, unemployment, consumption expectation, family income, and others.

Because the purpose of this study is based on the resolution on credit portability, data regarding the number of transferred transactions as well as the volume and average value per month were also collected and used as control variable.

\section{Analysis of Results}

Independent of the fixed-effect variables considered, that is, for the difference in differences baseline specified regressions, the results in Table 3 indicate that, with $99 \%$ confidence, the treatment has an effect for the analyzed group. Regression (7), which considers the fixed-effect variables of date, financial institution, type of credit, type of charge, and type of borrower, presents the highest R-squared among all of the baseline specified regressions, 0.737 , indicating that $73.7 \%$ of the spread variation is explained by the model used.

As indicated by the coefficients, the treated group paid 3.02 p.p. per month of additional spread, compared to the untreated group after controlling for fixed effects. After the change in the portability law, the spread is $0.66 \mathrm{pp}$ higher than that before Resolution 4,292. Comparing the two 
Table 3. Results obtained for specified regressions.

\begin{tabular}{|c|c|c|c|c|c|c|c|c|c|c|c|c|}
\hline & \multicolumn{9}{|c|}{ Differences in Differences } & \multicolumn{3}{|c|}{ Matching } \\
\hline & \multicolumn{7}{|c|}{ Baseline specification } & \multirow{2}{*}{$\begin{array}{l}\text { Only Natural } \\
\text { Person }\end{array}$} & \multirow{2}{*}{$\begin{array}{l}\text { Natural Person + Legal } \\
\text { Person in the treatment } \\
\text { group }\end{array}$} & \multirow{2}{*}{$\begin{array}{l}\text { Baseline } \\
\text { specification }\end{array}$} & \multirow{2}{*}{$\begin{array}{l}\text { Only Natural } \\
\text { Person }\end{array}$} & \multirow{2}{*}{$\begin{array}{c}\text { Natural Person + Legal } \\
\text { Person in the treatment } \\
\text { group }\end{array}$} \\
\hline & (1) & (2) & (3) & (4) & (5) & (6) & (7) & & & & & \\
\hline \multirow{2}{*}{ Treatment } & $-0.330^{* * *}$ & $-5.971^{* * *}$ & $-5.971^{* * *}$ & $-5.638^{* * *}$ & $3.029 * * *$ & $3.028^{* * *}$ & $3.028^{* * *}$ & $-8.333^{* * *}$ & $9.821^{* * *}$ & $-8.731^{* * *}$ & $-9.710^{* *}$ & $9.396^{* *}$ \\
\hline & $(0.041)$ & $(0.573)$ & $(0.573)$ & $(0.467)$ & $(0.774)$ & $(0.774)$ & $(0.774)$ & $(0.581)$ & $(0.772)$ & $(0.619)$ & $(0.670)$ & $(0.841)$ \\
\hline \multirow{2}{*}{ Portability } & 0.680 & $0.318^{* * *}$ & $0.663^{* * *}$ & $0.667^{* * *}$ & $0.663^{* * *}$ & $0.663^{* * *}$ & $0.663^{* * *}$ & $1.660^{* * *}$ & $0.771^{* * *}$ & $-1.681^{* * *}$ & $0.982^{* * *}$ & $0.786 * * *$ \\
\hline & $(0.048)$ & $(0.096)$ & $(0.114)$ & $(0.114)$ & $(0.114)$ & $(0.114)$ & $(0.114)$ & $(0.323)$ & $(0.144)$ & $(0.332)$ & $(0.236)$ & $(0.152)$ \\
\hline \multirow{2}{*}{ Treatment ${ }^{*}$ Portability } & \multirow{2}{*}{$\begin{array}{c}-0.386 * * * \\
(0.064)\end{array}$} & \multirow{2}{*}{$\begin{array}{c}-0.554^{* * *} \\
(0.087)\end{array}$} & \multirow{2}{*}{$\begin{array}{c}-0.554^{* * *} \\
(0.087)\end{array}$} & \multirow{2}{*}{$\begin{array}{c}-0.554^{* * *} \\
(0.088)\end{array}$} & \multirow{2}{*}{$\begin{array}{c}-0.554^{* * *} \\
(0.087)\end{array}$} & \multirow{2}{*}{$\begin{array}{c}-0.554^{* * *} \\
(0.087)\end{array}$} & \multirow{2}{*}{$\begin{array}{c}-0.554^{* * *} \\
(0.087)\end{array}$} & $-1.512^{* * *}$ & \multirow{2}{*}{$\begin{array}{c}-0.502 * * * \\
(0.121)\end{array}$} & $-1.497 * * *$ & $-0.897^{* * *}$ & $-0.524^{* * *}$ \\
\hline & & & & & & & & $(0.301)$ & & $(0.301)$ & $(0.178)$ & $(0.124)$ \\
\hline Control Variables & No & Yes & Yes & Yes & Yes & Yes & Yes & Yes & Yes & Yes & Yes & Yes \\
\hline Fixed-Effect Data & No & No & Yes & Yes & Yes & Yes & Yes & Yes & Yes & Yes & Yes & Yes \\
\hline Fixed-Effect Institution & No & No & No & Yes & Yes & Yes & Yes & Yes & Yes & Yes & Yes & Yes \\
\hline Fixed-Effect Modality & No & No & No & No & Yes & Yes & Yes & Yes & Yes & Yes & Yes & Yes \\
\hline Fixed-Effect Charge & No & No & No & No & No & Yes & Yes & Yes & Yes & Yes & Yes & Yes \\
\hline Fixed-Effect Type of Borrow & No & No & No & No & No & No & Yes & No & Yes & Yes & No & Yes \\
\hline $\mathrm{N}$ & 47,910 & 26,325 & 26,325 & 26,325 & 26,325 & 26,325 & 26,325 & 13,704 & 26,325 & 11,258 & 11,258 & 22,802 \\
\hline R-squared & 0.0102 & 0,3996 & 0.3705 & 0.5168 & 0.7306 & 0,7307 & 0,7307 & 0.7711 & 0.728 & 0.8269 & 0.8279 & 0.7944 \\
\hline
\end{tabular}

Robust standard errors are reported in parentheses. *,**,*** indicate significance at the $10 \%, 5 \%$ and $1 \%$

Source: Author. 
groups after the change in portability, we observe that the spread for the treated group is 0.55 p.p. lower than the spread for the untreated group.

With respect to the signals obtained for the variables in the specified regressions, the result of the iteration between portability and treatment presents a negative signal, as expected. When the individual belongs to the treatment group and the change in the portability resolution has already occurred, the observed spread is lower. The portability variable shows a positive signal, which was not expected. This result suggests that after the change in credit portability, the spread in the financial market was higher than that before Resolution 4,292.

Regarding the treatment variable, to include the fixed effect of the type of credit, the impact of being a natural person indicates a lower spread. However, the expected behavior would be the opposite because the spread obtained by loans for legal persons is lower than that for natural persons. Therefore, controlling for the characteristics of each type of credit, we obtain the expected signal. This change may have occurred as a result of loans at regulated rates for natural persons, which have a significantly lower credit spread than other modalities, regardless of the type of borrower.

Therefore, we cannot reject hypothesis because, as expected, Resolution 4,292 on credit portability reduced the spread practiced by financial institutions for the groups that were affected by the resolution.

We changed the treatment group used to eliminate any possible risks of comparing groups that may behave differently. The results presented in Table 3 indicate that regardless of whether the analysis considers only a natural person $^{9}$ on both treated and untreated groups or a

\footnotetext{
${ }^{9}$ Combination of shorter term loans from natural person on the untreated group in comparison to long term loans from natural person on the treated group.
} 
combination $^{10}$ of natural persons and legal persons on those groups, the change in the portability resolution had an impact on the reduction of the spread practiced in the Brazilian market.

Finally, Table 3, indicates the results obtained with the matching, that is, the result obtained when the untreated group considers only observations that present characteristics similar to the observations from the treatment group in the month prior to the implementation of Resolution 4,292. As with the other models used in this study, the results indicate that the spread practiced in the market was lower after the portability law for the treatment group compared to the control group. Comparing the difference in differences regression results with the matching results, we identify that the R-squared using matching is larger; that is, such models have greater explanatory power.

Figure 4 presents the behavior of the spread practiced by the treatment group versus the control group, both before and after the change in the legislation on credit portability. It is understood that after changing this resolution, the spread practiced by the treatment group suffered a smaller increase compared to the control group. The spread of the treatment group rose by approximately 0.5 p.p. ( $25 \%$ elevation), whereas the control group increased by approximately 3 p.p. (37.5\% elevation) after the change in the resolution.

The spread practiced in the treatment group, approximately $2 \%$, presents a lower value than the spread practiced by the control group, approximately $8 \%$. Given this scenario, we opted to analyze the percentage variation of the spread, naturally beyond the spread level already indicated above. Evaluating Figure 5, we observe that the cumulative variation in the spread, after the change

\footnotetext{
${ }^{10}$ Combination of shorter term loans from natural person and legal person on the untreated group in comparison to long term loans from natural person and legal person on the treated group.
} 
in the portability resolution, increased for the control group but presented a drop for the treatment group, which is in line with the statistical results presented above.

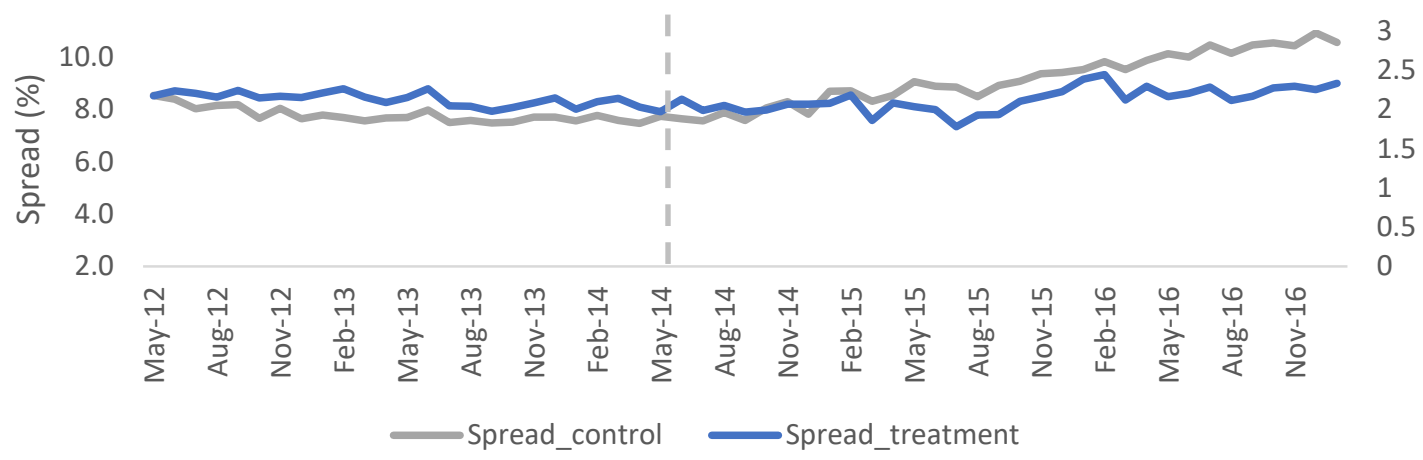

Figure 4. Behavior of the spread practiced by the untreated and treatment group Source: Author.

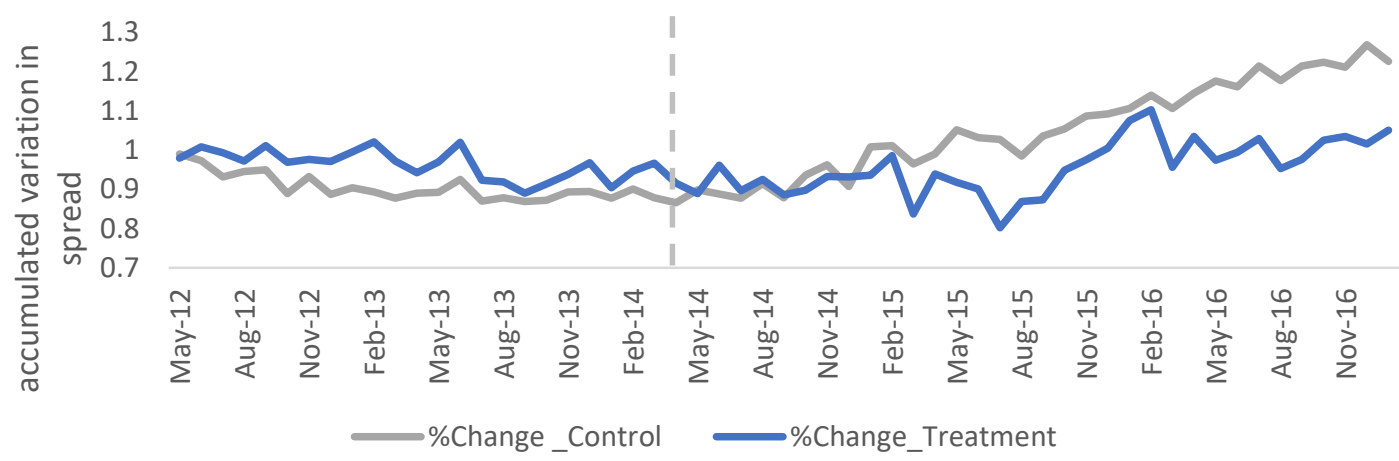

Figure 5. Behavior of the spread variation practiced by the untreated and treatment group Source: Author.

Analyzing the behavior of the group not impacted by this resolution, we note that the spread has grown year after year after the change in the portability legislation whereas the spread practiced by the treated group shows a downward trend in the period from one year after implementation of the new portability rules. It is worth noting that in the period from May 2015 to February 2016, this downward trend in the treatment group was changed, most likely due to the increase in the interest rate practiced by state-owned banks in Brazil as a result of the government decision to intervene in the credit market with regulated rates ${ }^{11}$. After this period, we have already observed a 
further drop in the variation of the spread practiced for this public, whereas the spread variation practiced for the group not affected by the resolution continues to grow. At the end of two years, the spread of the control group remains significantly higher than the spread of the treatment group.

\section{Conclusion}

This study contributes to in-depth knowledge on the issue of credit portability and its impacts on the credit market, for both borrowers and creditors.

The study indicates that, as expected, Resolution 4,292 on credit portability led to a reduction of the spread charged for the credit impacted by this resolution (credit provided to natural persons, with the exception of revolving credit), compared to the credit that was not the subject of the $\mathrm{BCB}$ resolution. Comparative graphical analyses between the two groups show that the spread for the treatment group is economically and significantly lower than that for the control group. Loans in the treatment group have a spread between 0.5 p.p. and 1.5 p.p. lower due to the new portability legislation.

This reduction can be explained by the reduction in the market power of the institutions that operate in the sector because this legislation facilitates the exchange of financial institutions by the clients, making the substitute credits more similar and reducing the costs of change.

Future studies could include a hypothesis related to increased/decreased banking concentration. Increased competition in this market could change the number of companies participating in the market, reducing concentration. It is expected that the more competitive the market, the greater the number of companies competing in the market. Therefore, companies should compete more in the loan market affected by this resolution. This assumption would corroborate our hypothesis that the change in Resolution 4,292 increased competition among the companies participating in the Brazilian credit market. 
On the other hand, as highlighted by Almeida (2015), in the medium/long term, only the strongest companies will be kept in the market, thus reducing the number of competitors in the market, which may lead to an oligopoly. However, spreads remain lower even after two years.

\section{Referências bibliográficas}

Abadie, Alberto, and Guido W Imbens. 2011. "Bias-Corrected Matching Estimators for Average Treatment Effects.” Journal of Business \& Economic Statistics 29 (1). Taylor \& Francis: 111.

Almeida, Diego Ferreira de. 2015. “Competição Entre Dinâmica Individual E Coletiva Em Modelos de Agentes Econômicos.” Universidade de São Paulo.

BACHA, Edmar. 1997. "O Plano Real E Outras Experiências Internacionais de Estabilização.” Brasília: IPEA/CEPAL.

BCB, BANCO CENTRAL DO BRASIL. 2013. "Resolução Nº 4.292."

—. 2014. “CONSUMO E FINANÇAS: Portabilidade Do Crédito - Novas Regras.”

—.2017a. "Homepage." http://www.bcb.gov.br.

- 2017b. "Relatório de $\quad$ Evolução $\quad$ Do $\quad$ SFN." http://www.bcb.gov.br/htms/deorf/r199812/texto.asp?idpai=revsfn199812.

Besanko, David, David Dranove, Mark Shanley, and Scott Schaefer. 2009. A Economia Da Estratégia-3. Bookman Editora.

Bignotto, Fernando G, and Eduardo Augusto de Souza Rodrigues. 2005. "IV-Fatores de Risco E O Spread Bancário No Brasil.” Relatório de Economia Bancária E Crédito, 45.

CADE, Conselho Administrativo de Defesa Econômica. 2016. "Guia Para Analise de Atos de Concentracao Horizontal."

Collin-Dufresn, Pierre, Robert S Goldstein, and J Spencer Martin. 2001. "The Determinants of 
Credit Spread Changes." The Journal of Finance 56 (6). Wiley Online Library: 2177-2207.

Dantas, José Alves, Otávio Ribeiro de Medeiros, and Lúcio Rodrigues Capelleto. 2012. “Determinantes Do Spread Bancário Ex Post No Mercado Brasileiro." RAM. Revista de Administração Mackenzie 13 (4). Universidade Presbiteriana Mackenzie.

Djankov, Simeon, Caralee McLiesh, and Andrei Shleifer. 2007. "Private Credit in 129 Countries." Journal of Financial Economics 84 (2). Elsevier: 299-329.

FEBRABRAN, Federação Brasileira de Bancos. 2015. "RELATÓRIO ANUAL." relatorioanual2015.febraban.org.br.

Laux, Guilherme. 2013. "Mercado de Crédito No Brasil: Características E Respostas a Choques." Lavoratti, Liliana. 2010. "Concorrência E Explosão Do Crédito.” Revista Conjuntura Econômica 64 (4): $20-35$.

Martins, Bruno. 2012. "Estrutura de Mercado Local E Competição Bancária: Evidências No Mercado de Financiamento de Veículos." Trabalhos Para Discussão Noo 1028-1519.

Matthews, Kent Gerard Patrick, and John Thompson. 2008. The Economics of Banking. Wiley.

Oreiro, José Luís da Costa, Luiz Fernando de Paula, Guilherme Jonas Costa da Silva, and Fábio Hideki Ono. 2006. "Determinantes Macroeconômicos Do Spread Bancário No Brasil: Teoria E Evidência Recente.” Economia Aplicada 10 (4). SciELO Brasil: 609-34.

Pereima, João Basilio, and Rafael Camargo de Pauli. 2008. "O Setor Bancário No Brasil: Transformações Recentes, Rentabilidade E Contribuições À Atividade Econômica.” Revista Economia \& Tecnologia 4 (1).

Rocha, Felipe Medeiros, and José Luís Oreiro. 2009. "Um Modelo de Determinantes Macroeconômicos Do Spread Bancário Aplicado Aos Grandes Bancos Brasileiros.” Universidade de Brasília.

Wooldridge, Jeffrey M. 2006. Introdução À Econometria: Uma Abordagem Moderna. Pioneira 
Thomson Learning. 